\title{
PENGARUH SELEBRITY ENDORSER, CITRA MEREK DAN HARGA TERHADAP KEPUTUSAN PEMBELIAN KOSMETIK WARDAH (STUDI KASUS MAHASISWI ASRAMA UNDHARI)
}

\author{
Munawaroh $^{1}$, Yesi Gusteti ${ }^{2}$, Fenisi Resty 3 \\ Universitas Dharmas Indonesia ${ }^{1,2,3}$
}

\begin{abstract}
munawarohw302@gmail.com; ygusteti@gmail.com²; restydeffi19@gmail.com³
\end{abstract}
\begin{abstract}
ABSTRAK
Penelitian ini dilakuan untuk mengetahui dan menganalisis seperti apa dampak yang ditimbulkan oleh celebrity endorser, citra merek dan harga terhadap keputusan pembelian kosmetik wardah pada mahasiswi asrama Undhari. Tujuan penelitian ini dilakukan untuk mengetahui dan menganalisis "Pengaruh celebrity endorser, citra merek dan harga terhadap keputusan pembelian kosmetik wardah" (studi kasus mahasiswi asrama Undhari). Penelitian ini menggunakan metode kuantitantif, teknik pengembilan sampel menggunakan non proaility sampling pengambilan data menggunakan kuesioner, responden yang di jadikan sampel adalah sebanyak 105 reponden. Hasil dari penelitian ini menunjukan bahwa secara parsial dan simultan terbukti bahwa celebrity endorser, citra merek dan harga berpengaruh secara signifikan terhadap keputusan pembelian. Nilai Adjusted R Square nya adalah 0,789 yang berarti semua variable independen dapat menjelaskan sebesar $78,9 \%$ terhadap variable dependen. Sementara sisanya $21,1 \%$ dapat dijelaskan oleh faktorl ainnya yang tidak diuji dalam penelitian ini.
\end{abstract}

Kata Kunci : celebrity endorser, citra merek, harga, keputusan pembelian

\begin{abstract}
This research was conducted to find out and analyze the impact of celebrity endorser, brand image and price on purchasing decisions of Wardah cosmetics in Undhari dormitory students. The purpose of this study was to identify and analyze "The influence of celebrity endorser, brand image and price on the purchasing decision of Wardah cosmetics" (case study of Undhari dormitory student). This study used a quantitative method of collecting data using a questionnaire, the respondents who were used as samples were 105 respondents.The results of this study indicate that partially and simultaneously it is proven that celebrity endorser, brand image and price have a significant effect on purchasing decisions. The value of Adjusted $R$ Square is 0,789 , which means that all independent variables can explain $78.9 \%$ of the dependent variable. While the remaining $21.1 \%$ can be explained by other factors not tested in this study.
\end{abstract}

Keywords : celebrity endorser, brand image, price, purchase decision

Diterima: 15 Agustus 2021; Direvisi: 27 September 2021; Diterbitkan: Oktober 2021

\section{PENDAHULUAN}

Wardah adalah produk kosmetik dengan label halal yang diproduksi oleh PT Paragon Technology and Innovation.
Wardah merupakan salah satu brand berhasil menjadi Top Brand Indonesia dibandingkan dengan brand lainnya yang diproduksi oleh PT Paragon Technology and Innovation, seperti Make Over, Putri, 
Emina Vivre, dan IX. Dewi Sandra, Zaskia Sungkar, Ayana, Fenita Arie, Natasha Rizky dan Dian Pelangi merupakan celebrity endorser wardah. Wardah sebagai produk kosmetik yang berlabel halal terkemuka di Indonesia menjadikan Dewi Sandra, Zaskia Sungkar dan Dian Pelangi sebagai brand ambassador, karena mempresentasikan seorang wanita muslimah juga dapat merias wajah tanpa ada rasa khawatir ketika akan melaksanakan ibadah.

Karena, produk wardah ini halal dan sah terutama untuk melaksanakan ibadah. Dengan ada nya persepsi kosmetik yang berlabel halal, wardah tidak mengkhususkan produknya untuk wanita berhijab dan bukan hanya orang muslim saja, karena dengan adanya label halal tersebut terbukti bahwa halal itu aman. Muncul nya trend masa kini dengan adanya wanita ingin selalu mempercantik diri.

Universitas Dharmas Indonesia merupakan kampus terbesar di Dharmasraya dengan populasi keseluruhan mahasiswi asrama dari tahun 2017 sampai 2020 mempunyai jumlah sebesar 799 mahasiswi sehingga produk kosmetik merupakan produk yang potensial bagi pasar mahasiswi dan sebuah produk yang memiliki label halal merupakan produk yang sensitive, karena konsumen mengganggap bahwa ketidak halalan sebuah produk akan berakibat tidak baik kepada dirinya dimasa sekarang maupun yang akan datang.

Tujuan dari penelitian ini adalah Untuk menganalisis dan mengetahui pengaruh celebrity endorser, citra merek dan harga terhadap keputusan pembelian kosmetikwardah pada mahasiswi asrama Undhari.

\section{LANDASAN TEORI}

\section{Celebrity endorser}

Celebriry endroser dapat menarik minat konsumen untuk melakukan keputusan pembelian produk, kredibilitas selebriti adalah salah satu faktor yang mempengaruhi proses keputusan pembelian produk, menggunakan celebrity endorser dapat meningkatkan brand awareness, encourage trial, dan tentunya meningkatkan brand image atau citra merek. (Febriani 2020)

\section{Citra merek}

Citra merek (Brand Image) merupakan representasi dengan dari keseluruhan persepsi terhadap merek yang dibentuk dari informasi dan pengalaman masa lalu terhadap merek tersebut. Citra terhadap merek berhubungan sikap yang berupa keyakinan dan preferensi terhadap suatu merek. (Aqmarina 2016). Citra merek yang terdiri dari brand image, brand experience, brand identity, brand loyalty and brand value juga dipengaruhi oleh kualitas pelayanan yang prima dan promosi produk dari perusahaan untuk menarik konsumen mengambil keputusan sehingga konsumen merasa puas (Soehardi, 2020).

\section{Harga}

Harga merupakan suatu cara bagi seorang penjual untuk membedakan penawarannya dari para pesaing. Sehingga penetapan harga dapat dipertimbangkan sebagai bagian dari fungsi diferensiasi barang dalam pemasaran. (Pangastuti 2019) (Murdayani et al., 2021)

\section{Keputusan pembelian}

Keputusan pembelian merupakan keputusan konsumen untuk membeli suatu produk setelah sebelumnya memikirkan tentang layak tidaknya membeli produk itu 
dengan mempertimbangkan informasiinformasi yang ia ketahui dengan relitas tentang produk itu setelah ia menyaksikannya. (Gloria 2018)

\section{Pengembangan Hipotesis \\ Keterkaitan Variabel Celebrity Endorser Terhadap Keputusan Pembelian}

Berdasarkan hasil penelitian (Aqmarina 2016) menunjukkan bahwa celebrity endorser memiliki pengaruh yang positif dan signifikan terhadap keputusan pembelian sebesar, karna konsumen tertarik pada merek yang menggunakan celebrity endorser, celebrity endorser membantu untuk mengenali produk, memberikan citra yang positif pada produk sehingga konsumen melakukan keputusan pembelian. Masyarakat tersebut lebih mudah dipengaruhi dengan menggunakan strategi Celebrity Endorsement untuk keputusan pembelian mereka. Oleh karena itu, konsumen akan lebih memiih produk berdasarkan selebriti pendukung ketika mereka benar-benar tidak tahu tentang merek tersebut.

H1: Diduga variabel celebrity endorser berpengaruh positif dan segnifikan terhadap keputusan pembelian

Keterkaitan Variabel Citra Merek Terhadap Keputusan Pembelian

Berdasarkan hasil penelitian (Hamdani 2018) menunjukkan bahwah citra merek bagian sebuah produk yang membawa informasi verbal tentang produk atau tentang penjualannya, merek memegang peranan penting dalam pemasaran, merek yang dibeli konsumen adalah merek yang memiliki keunikan individual yang tidak sama satu dengan yang lainnya, merek menempel dalam persepsi pelanggan, sehingga sesungguhnya persaingan yang terjadi adalah pertarungan persepsi merek diatas pertarungan produk.

H2: Diduga variabel citra merek berpengaruh positif dan signifikan terhadap keputusan pembelian.

\section{Keterkaitan Harga Terhadap Keputusan Pembelian}

Berdasarkan hasil penelitian (Ayuniah 2014) menunjukkan bahwah harga berpengaruh signifikan terhadap keputusan pembelian, karena sejumlah uang yang ditukarkan untuk sebuah produk dan jasa. Lebih jauh lagi, sejumlah nilai yang konsumen tukarkan untuk jumlah manfaat dengan memiliki atau menggunakan suatu barang atau jasa, harga merupakan hal yang diperhatikan konsumen saat melakukan pembelian.

H3 : Diduga veriabel harga berpengaruh positif dan signifikan terhadap terhadap keputusan pembelian

\section{Keterkaitan Variabel Celebrity Endorser, Citra Merek dan Harga Terhadap Keputusan Pembelian}

Berdasarkan hasil penelitian (Agung 2020) menunjukkan bahwa celebrity endorser, citra merekdan harga secara bersama-sama berpengaruh positif dan signifikan terhadap keputusan pembelian, Dalam menentukan keputusan pembelian suatu produk, konsumen akan melewati beberapa proses, sebelum akhirnya memutuskan untuk membeli produk tersebut.

H4 : Diduga variabel celebrity endorser, citra merek dan harga berpengaruh positif dan signifikan terhadap keputusan pembelian 


\section{Keranga Penelitian}



Gambar 1. Kerangka Penelitian

\section{METODE PENELITIAN}

Populasi dalam penelitan ini yaitu pengguna kosmetik wardah pada mahasiswi universitas dharmas indonesia dengan sampel sebanyak 105 responden. Penelitian ini menggunakan metode penelitian kuantitatif dengan enggunakan kuisioner, penarikan sampel dilakukan dengan menggunakan teknik non probability sampling. Sumber data menggunakan data primer dan data sekunder. Metode pengumpulan data yang digunakan adalah kuesioner.

Penelitian ini dilaksanakan di asrama Universitas Dharmas Indonesia dengan sampel diambil dari mahasiswi asrama Universitas Dharmas Indonesia yang menggunakan produk kosmetik wardah waktu pelaksanaan penelitian dari tanggal 27April - 30Mei 2021 dan pengumpulan data pada tanggal 1 - 30 Juni tahun 2021.

Variabel independen yang digunakan dalam penelitian ini adalah celebrity endorser, citra merek dan harga

1) Celebrity endorser (X1) merupakan pendukung dari suatu produk yang berperan sebagai penyampai pesan untuk memperkuat citra sebuahmerek.

2) Citra merek (X2) merupakan apa yang dipersepsikan oleh konsumen mengenai sebuahmerek
3) Harga ( $\left.\mathrm{X}_{3}\right)$ merupakan yang harus diserahkan pelanggan untuk mendapatkan manfaat produk yg ditawarkan bersama bauran pemasaranperusahaan

4) Variabel dependen yang digunakan dalam penelitian ini adalah keputusan pembelian, variabel terikat merupakan variabel yang dipengaruhi atau yang menjadi akibat karena adanya variabel bebas. Variabel dependen dalam penelitian ini adalah keputusan pembelian.

\section{HASIL PENELITIAN DAN PEMBAHASAN}

\section{Uji validitas}

Hasil uji validitas digunakan untuk mengukur sah atau valid tidaknya suatu kuesioner. Pengujian valid dengan membandingkan nilai $r$ hitung (untuk $r$ hitung tiap butir dapat dilihat pada tampilan Output Crnbach Alpha pada kolom Corrected Item Total Correlation) dengan $r$ tabel $(0,195)$ jika nilai $r$ hitung lebih besar dari $\mathrm{r}$ tabel, maka butir pernyataan dinyatakan valid. Hasil uji validitas kuesioner penelitian di jelaskan pada tabel berikut:

Tabel 1. Hasil Uji Validitas Celebrity Endorser (X1), Citra Merek (X2), Harga (X3) dan Keputusan Pembelian (Y)

\begin{tabular}{|c|c|c|c|c|}
\hline Variabel & $\begin{array}{l}\text { Kode } \\
\text { item }\end{array}$ & $r$ hitung & $r$ tabel & $\begin{array}{l}\text { Keteran } \\
\text { gan }\end{array}$ \\
\hline \multirow{7}{*}{$\begin{array}{l}\text { Celebrity } \\
\text { Endorser } \\
(X 1)\end{array}$} & X1.1 & 0,532 & 0,195 & \multirow{7}{*}{ Valid } \\
\hline & $\mathrm{X} 1.2$ & 0,605 & 0,195 & \\
\hline & $\mathrm{X} 1.3$ & 0,680 & 0,195 & \\
\hline & $\mathrm{X} 1.4$ & 0,454 & 0,195 & \\
\hline & $\mathrm{X} 1.5$ & 0,549 & 0,195 & \\
\hline & X1.6 & 0,529 & 0,195 & \\
\hline & $\mathrm{X} 1.7$ & 0,588 & 0,195 & \\
\hline \multirow{7}{*}{$\begin{array}{c}\text { Citra } \\
\text { Merek } \\
(\mathrm{X} 2)\end{array}$} & $\mathrm{X} 2.1$ & 0,509 & 0,195 & \multirow{7}{*}{ Valid } \\
\hline & $\mathrm{X} 2.2$ & 0,578 & 0,195 & \\
\hline & X2.3 & 0,637 & 0,195 & \\
\hline & X2.4 & 0,545 & 0,195 & \\
\hline & X2.5 & 0,554 & 0,195 & \\
\hline & X2.6 & 0,599 & 0,195 & \\
\hline & X2.7 & 0,484 & 0,195 & \\
\hline
\end{tabular}




\begin{tabular}{|c|c|c|c|c|}
\hline \multirow{5}{*}{ Harga $\left(X_{3}\right)$} & $\mathrm{X}_{3.1}$ & 0,752 & 0,195 & \multirow{5}{*}{ Valid } \\
\hline & $\mathrm{X}_{3.2}$ & 0,648 & 0,195 & \\
\hline & $\mathrm{X}_{3.3}$ & 0,472 & 0,195 & \\
\hline & $\mathrm{X}_{3.4}$ & 0,432 & 0,195 & \\
\hline & $\mathrm{X}_{3.5}$ & 0,587 & 0,195 & \\
\hline \multirow{7}{*}{$\begin{array}{l}\text { Keputusan } \\
\text { Pembelian } \\
\text { (Y) }\end{array}$} & Y.1 & 0,456 & 0,195 & \multirow{7}{*}{ Valid } \\
\hline & Y.2 & 0,663 & 0,195 & \\
\hline & Y.3 & 0,689 & 0,195 & \\
\hline & Y.4 & 0,531 & 0,195 & \\
\hline & Y.5 & 0,668 & 0,195 & \\
\hline & Y.6 & 0,652 & 0,195 & \\
\hline & Y.7 & 0,359 & 0,195 & \\
\hline
\end{tabular}

Sumber : Data Olahan SPSS 28.00, 2021

Berdasarkan perbandingan antara $r$ hitung dan r- table maka dapat disimpulkan bahwa semua butir soal untuk variable celebrity endorser (X1), citra merek (X2), harga (X3) dan keputusan pembelian (Y) adalah valid.

\section{Uji Reliabilitas}

\section{Pengujian reliabilitas dilakukan untuk menilai konsistensi jawaban responden. Suatu variabel dikatakan reliabel jika nilai Cronbach Alpha > 0,07. Hasil uji ini reliabilitas instrumen penelitian dijelaskan pada tabel berikut:}

Tabel 2. Hasil Uji Reliabiliti Celebrity Endorser (X1), Citra Merek (X2), Harga (X3) dan Keputusan Pembelian (Y)

\begin{tabular}{|c|c|c|c|}
\hline Variabel & $\begin{array}{l}\text { Cronbach } \\
\text { alpha }\end{array}$ & Rule & $\begin{array}{l}\text { kesimpula } \\
\mathrm{n}\end{array}$ \\
\hline $\begin{array}{l}\text { Celebrity } \\
\text { endorser } \\
\text { (X1) }\end{array}$ & 0,728 & 0,7 & Reliabel \\
\hline $\begin{array}{l}\text { Citra } \\
\text { merek(X2) }\end{array}$ & 0,726 & 0,7 & Reliabel \\
\hline Harga $\left(\mathrm{X}_{3}\right)$ & 0,722 & 0,7 & Reliabel \\
\hline $\begin{array}{l}\text { Keputusan } \\
\text { pembelian } \\
\text { (Y) }\end{array}$ & 0,736 & 0,7 & Reliabel \\
\hline
\end{tabular}

Berdasarkan hasil pengujian dapat dijelaskan bahwah nilai Cronbach Alpha > 0,07 sehingga dapat disimpulkan bahwa semua instrumen tersebut reliabel.
Interprestasi dari hasil analisis tabel di atas dapat dilihat Korelasi anatara variable celebrity endorser,citramerek dan harga terhadap keputusan pembelian adalah signifikan.

Tabel 3. Hasil Analisis Korelasi Variabel Celebrity Endorser (X1), Citra Merek (X2), Harga (X3) Dan Keputusan Pembelian (Y)

\begin{tabular}{|c|c|c|c|c|c|}
\hline & & Corr & lation & & \\
\hline & & $\begin{array}{l}\text { Celebrity } \\
\text { Endorser }\end{array}$ & $\begin{array}{l}\text { Citra } \\
\text { merek }\end{array}$ & Harga & $\begin{array}{l}\text { Keputusan } \\
\text { pembelian }\end{array}$ \\
\hline $\begin{array}{l}\text { Celebrity } \\
\text { Endorser }\end{array}$ & \begin{tabular}{|l|} 
Pearson \\
Correlation
\end{tabular} & 1 &, $479^{* * *}$ &, $382^{* * *}$ & $312^{* * *}$ \\
\hline & Sig.(2-Tailed) & & <,001 & <,001 &, 001 \\
\hline & $\mathrm{N}$ & 105 & 105 & 105 & 105 \\
\hline $\begin{array}{l}\text { Citra } \\
\text { merek }\end{array}$ & \begin{tabular}{|l|} 
Pearson \\
Correlation
\end{tabular} & $479^{* * *}$ & 1 & $539^{* * *}$ & $385^{* * *}$ \\
\hline & Sig.(2-Tailed) & $<, 001$ & & <,001 & <,001 \\
\hline & $\mathrm{N}$ & 105 & 105 & 105 & 105 \\
\hline Harga & \begin{tabular}{|l|} 
Pearson \\
Correlation
\end{tabular} &, $382^{* * *}$ &, $539^{* * *}$ & 1 &, $409^{* * *}$ \\
\hline & Sig.(2-Tailed) & $<, 001$ & <,001 & & $<, 001$ \\
\hline & $\mathrm{N}$ & 105 & 105 & 105 & 105 \\
\hline $\begin{array}{l}\text { Keputusar } \\
\text { pembelia }\end{array}$ & $\begin{array}{l}\text { Pearson } \\
\text { Correlation }\end{array}$ &, $312^{* * *}$ &, $385^{* * *}$ & $409^{* * *}$ & 1 \\
\hline $\mathrm{n}$ & Sig.(2-Tailed) &, 001 & |<,001 & <,001 & \\
\hline & $\mathrm{N}$ & 105 & 105 & 105 & 105 \\
\hline
\end{tabular}

Sumber : Data Olahan SPSS 28,00, 2021

\section{Analisis Regresi Berganda}

Untuk mengetahui pengaruh antara celebrity endorser, citra merek, dan harga terhadap keputusan pembelian secara simultan dapat dilihat pada tabel berikut:

Tabel 4. Analisis Regresi Berganda Celebrity Endorser (X1), Citra Merek (X2) dan Harga $\left(\mathrm{X}_{3}\right)$ Terhadap Keputusan Pembelian (Y)

\begin{tabular}{|c|c|c|c|c|c|c|}
\hline & \multirow[b]{3}{*}{ Model } & \multicolumn{5}{|c|}{ Coefficientsa } \\
\hline & & \multicolumn{2}{|c|}{$\begin{array}{l}\text { Unstandardized } \\
\text { Coefficients }\end{array}$} & \multirow{2}{*}{$\begin{array}{c}\begin{array}{c}\text { Standardized } \\
\text { Coefficients }\end{array} \\
\text { Beta }\end{array}$} & \multirow[b]{2}{*}{$\mathrm{T}$} & \multirow[b]{2}{*}{ Sig. } \\
\hline & & B & Std. Error & & & \\
\hline \multirow[t]{4}{*}{1} & $\begin{array}{c}\text { (Constant } \\
\text { ) }\end{array}$ & 11,126 & 3,486 & & 3,191 & ,002 \\
\hline & $\begin{array}{l}\text { Celebrity } \\
\text { endorser }\end{array}$ & ,131 & , 108 & ,124 & 1,314 & ,001 \\
\hline & $\begin{array}{l}\text { Citra } \\
\text { merek }\end{array}$ & ,204 & ,124 & , 185 & 1,653 & ,001 \\
\hline & Harga & ,393 & ,159 & ,262 & 2,469 & ,000 \\
\hline
\end{tabular}

\section{Analisis Korelasi}


Berdasarkan tabel 4. di atas maka dapat dilihat persamaan regresi nya yaitu: $Y$ $=11,126+0,131+0,204+0,393+\mathrm{e}$

\section{Uji Normalitas}

Tabel 5. One-Sample Kolmogorov-Smirnov Test

\begin{tabular}{|c|c|c|}
\hline \multirow{2}{*}{\multicolumn{2}{|c|}{$\mathrm{N}$}} & Unstandardized Residual \\
\hline & & 105 \\
\hline Normal & Mean & .0000000 \\
\hline Rarametersabla & Std. Deviation & 2,16838365 \\
\hline Most Extreme & Absolute & , \\
\hline Differences & $\begin{array}{l}\text { Positive } \\
\text { Negative }\end{array}$ & $\begin{array}{r}, 055 \\
-, 096\end{array}$ \\
\hline Test Statistic & & , 096 \\
\hline Assmp, Sig. $(2-$ t) & ledes &, 225 \\
\hline Monte Carlo & Sig. &, 220 \\
\hline Sig. (2-tailed)d. & 9996 Confidence Lower Bound &, 016 \\
\hline
\end{tabular}

Sumber: Data Olahan SPSS 28.o, 2021

Berdasarkan hasil uji normalitas diketahui nilai signifikan 0,225 >0,05 maka dapat disimpulkan bahwa nilai residual berdistribusi normal.

\section{Uji Heterokedatisitas}

Berikut adalah hasil pengujian untuk mendeteksi ada atau tidak nya heterokedatisitas.

Tabel 6. Uji HeteroskedastisitasVariabelCelebrity Endorser (X1), Citra Merek (X2) Dan Harga (X3) Terhadap Keputusan Pembelian (Y)

\begin{tabular}{|c|c|c|c|c|c|c|}
\hline \multicolumn{7}{|c|}{ Coefficientsa } \\
\hline & \multirow[b]{2}{*}{ Model } & \multicolumn{2}{|c|}{$\begin{array}{c}\text { Unstandardiz } \\
\text { ed } \\
\text { Coefficients }\end{array}$} & \multirow{2}{*}{$\begin{array}{c}\begin{array}{c}\text { Standardiz } \\
\text { ed } \\
\text { Coefficient } \\
\mathrm{s}\end{array} \\
\text { Beta } \\
\end{array}$} & \multirow[b]{2}{*}{$\mathrm{T}$} & \multirow[b]{2}{*}{ Sig. } \\
\hline & & $\mathrm{B}$ & $\begin{array}{l}\text { Std. } \\
\text { Error }\end{array}$ & & & \\
\hline & $\begin{array}{l}\text { (Consta } \\
\text { nt) }\end{array}$ & $\begin{array}{l}11,1 \\
26\end{array}$ & 3,486 & & 3,191 &, 002 \\
\hline & $\begin{array}{l}\text { celebrit } \\
y \\
\text { endorse } \\
r\end{array}$ & ,131 & , 108 & ,124 & 1,314 & , ০০o \\
\hline & $\begin{array}{l}\text { Citrame } \\
\text { rek }\end{array}$ & $\begin{array}{l}, 20 \\
4\end{array}$ & ,124 & , 185 & 1,653 & , ০০1 \\
\hline & Harga &, 393 & ,159 &, 262 & 2,469 & ,oo1 \\
\hline
\end{tabular}

Sumber: Data Olahan SPSS 28.o, 2021

Sumber: Data Olahan SPSS 28.o, 2021 Dari hasil table coeffisien diatas yang di lihat adalah nilai signifikansinya. Variable independen memiliki nilaisignifikan > 0,05 maka bias dikatakan model penelitian ini tidak terjadi masalah heteroskedastisitas.

\section{Uji Multikolerasi}

Dari hasil tabel di atas, yang akan di nilai adalah nilai tolerance dan juga VIF nya, dapat dilihat bahwa nilai tolerance celebrity endorser (X1), citra merek (X2) dan harga $\left(X_{3}\right)$ lebih >0,10 maka artinya tidak terjadi multikolineriaritas, dan nilai VIF nya $\leq$ 10,00 maka artinya tidak terjadi multikoleniaritas.

Tabel 7. Uji Multikorelasi Variabel Celebrity Endorser (X1), Citra Merek (X2) Dan Harga (X3) Terhadap Keputusan Pembelian (Y)

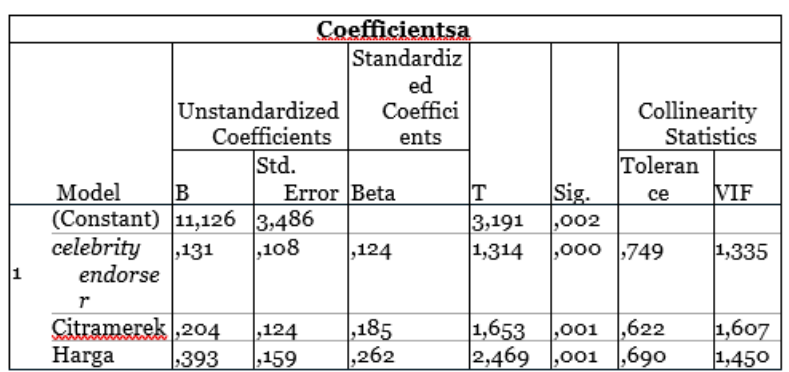

Sumber: Data Olahan SPSS 28.o, 2021

\section{Uji -T}

Derajat kebebasan (df) n-k-1 yaitu 105 - 3 - $1=101$ ( $n$ adalah jumlah responden dan $\mathrm{k}$ adalah jumlah variabel independent) sehingga hasil yang diperoleh untuk t-tabel sebesar 1,292. Dari hasil olah data dapat disajikan pada tabel berikut:

Tabel 8. Pengujian Hipotesis Secara Parsial (Uji T)

\begin{tabular}{|c|c|c|c|c|c|}
\hline \multicolumn{6}{|c|}{ Coefficientsa } \\
\hline \multirow[b]{2}{*}{ Model } & \multicolumn{2}{|c|}{$\begin{array}{c}\text { Unstandardized } \\
\text { Coefficients }\end{array}$} & \multirow{2}{*}{\begin{tabular}{|l}
$\begin{array}{c}\text { Standardize } \\
\mathrm{d} \\
\text { Coefficien } \\
\text { ts }\end{array}$ \\
Beta \\
\end{tabular}} & \multirow[b]{2}{*}{$\mathrm{T}$} & \multirow[b]{2}{*}{ Sig. } \\
\hline & $B$ & \begin{tabular}{|l} 
Std. \\
Error
\end{tabular} & & & \\
\hline (Constant) & 11,126 & $3,4^{86}$ & & 3,191 &, 002 \\
\hline $\begin{array}{c}\text { celebrity } \\
\text { endorse } \\
r\end{array}$ &, 131 &, 108 &, 124 & 1,314 & , , OOO \\
\hline citramerek &, 204 &, 124 &, 185 & 1,653 &, 001 \\
\hline Harga & 393 &, 159 &, 262 & 2,469 & ,001 \\
\hline
\end{tabular}

Sumber: Data Olahan SPSS 28.o, 2021

Pada tabel diatas dapat dilihat bahwa nilai rata-rata hingga interpretasinya menjadi sebagai berikut sesuai dengan tabel 
di atas yaitu hasil uji t menunjukan bahwa nilai signifikan celebrity endorser terhadap keputusan pembelian karena $0.000<0.05$ dan nilai t hitung 1,314 > t table 1,292 maka sig > 0,05 maka variable bebas berpengaruh signifikan terhadap variable terikat, maka $\mathrm{HO}$ ditolak dan $\mathrm{H} 1$ diterima. Selanjunya citra merek sesuai dengan tabel diatas yaitu hasil uji $t$ menunjukan bahwa nilai signifikan citra merek terhadap keputusan pembelian adalah $0,001<0,05$ dan nilai $t$ hitung 1,653>t tabel 1,292 maka Ho ditolak dan $\mathrm{H} 2$ diterima. Selanjutnya harga hasil uji t menunjukkan bahwa nilai signifikan harga terhadap keputusan pembelian adalah 0,001<0,05 dan nilai t hitung 2,469 > t tabel 1,292 maka Ho ditolak dan $\mathrm{H} 2$ di terima maka artinya terdapat pengaruh signifikan antara variabel celebrity endorser, citra merek dan harga terhadap keputusan pembelian..

\section{Uji-F}

Uji F menggunakan taraf signifikan 0,05 (uji 2 sisi) dengan derajat kebebasan df 2 (n$\mathrm{k}-1$ ) atau 105-3-1 = 101, maka hasil yang diperoleh untuk $\mathrm{F}_{\text {tabel }}$ sebesar 3,09.

Tabel 9. Pengujian Hipotesis Secara Bersama-Sama (Uji F)

\begin{tabular}{|c|c|c|c|c|c|c|}
\hline \multicolumn{7}{|c|}{ ANOVA } \\
\hline \multicolumn{2}{|r|}{ Model } & $\begin{array}{r}\text { Sum of } \\
\text { Squares }\end{array}$ & Df & $\begin{array}{l}\text { Mean } \\
\text { Square }\end{array}$ & $\mathrm{F}$ & Sig. \\
\hline & Regression & $13,5,194$ & 3 & $4.5,065$ & 9,308 & $<, O O 1^{b}$ \\
\hline & Residual & 488,996 & 101 & 4,842 & & \\
\hline & Total & 624,190 & 104 & & & \\
\hline
\end{tabular}

Sumber: Data Olahan SPSS 28.o, 2021

Dari tabel di atas dapat dilihat pengujian ini dilakukan dengan cara membandingkan nilai $\mathrm{F}$ hitung dengan $\mathrm{F}$ tabel karena nilai $\mathrm{F}$ hitung lebih besar dari nilai $\mathrm{F}$ tabel $(9,308$ $>$ 3,09). Nilai $F$ 9,308 dengan tingkat signifikan $(0,001<0,005)$. Maka diperoleh Ho ditolak dan $\mathrm{H}_{4}$ diterima, yang berarti hal ini dilakukan secara bersama-sama antara celebrity endorser, citra merek dan harga berpengaruh signifikan terhadap keputusan pembelian.

\section{KoefisienDeterminasi( $\left.\mathbf{R}^{2}\right)$}

Hasil determinasi dapat dilihat pada tabel sebagai berikut:

Tabel 9. Hasil Pengujian Determinasi $\left(\mathrm{R}^{2}\right)$

\begin{tabular}{|c|c|c|c|c|}
\hline \multicolumn{5}{|c|}{ Model Summary } \\
\hline Model & $\mathrm{R}$ & R Square & $\begin{array}{l}\text { Adjusted } \\
\text { Square }\end{array}$ & $\begin{array}{l}\text { Std. Error of } \\
\text { the Estimate }\end{array}$ \\
\hline & ,892a &, 79 & ,789 & ,750 \\
\hline
\end{tabular}

Sumber: Data Olahan SPSS 28.o, 2021

Berdasarkan tabel di atas diperoleh angka $\mathrm{R}$ Square sebesar 0,892 hal ini menunjukan bahwa sumbangan variable celebrity endorser, citra merek dan harga terhadap keputusan pembelian sebesar 0,789. yang artinya bahwa pengaruh varibel citra merek terhadap keputusan pembelian sebesar $\quad 78,9 \% \quad$ sedangkan $21,1 \%$ dipengaruhi oleh faktorlain.

\section{Analisis Keterkaitan Variable Celebrity Endorser Terhadap Keputusan Pembelian}

Berdasarkan penelitian yang dilakukan oleh (Aqmarina 2016) hasil penelitiannya yang diperoleh adalah ada nya korelasi positif antara variable celebrity endorser dengan keputusan pembelian. Nilai yang di tunjukkan pada koefisien jalur $(\beta)$ adalah sebesar 0,515 , signifikan dengan probabilitas sebesar $0,000 \quad(p<0,05)$ berdasarkan hasil tersebut menunjukkan bahwa celebrity endorser memiliki pengaruh yang positif dan signifikan terhadap keputusan pembelian sebesar $51,5 \%$.

\section{Analisis Keterkaitan Variable Citra Merek Terhadap Keputusan Pembelian}

Berdasarkan penelitian yang dilakukan oleh (Aktif, farina 2015) hasil 
penelitiannya diperoleh nilai $t$ hitung sebesar 2,658 dengan t table sebesar 1,985 sehingga variabel Citra merek memiliki pengaruh yang signifikan terhadap Keputusan Pembelian. Jika dilihat dari nilai signifikansi t sebesar 0,009 lebih kecil dari alpha yang dipakai yaitu 0,009 $<0,05$. Sehingga dapat disimpulkan Citra Merek mempunyai pengaruh yang signifikan terhadap Keputusan Pembelian.

\section{Analisis Keterkaitan Variable Harga Terhadap Keputusan Pembelian}

Berdasarkan penelitian yang dilakukan oleh (Pangastuti 2019) telah membuktikan bahwa terdapat pengaruh antara harga terhadap keputusan pembelian diketahui nilai Thitung sebesar 3,225 > nilai dari $\mathrm{T}$ table sebesar 2,052 dan nilai signifikansi sebesar $0,003<0,5$ maka Ho ditolak dan $\mathrm{Ha}$ diterima yang artinya kualitas produk berpengaruh terhadap keputusan pembelian. Kualitas produk berpengaruh terhadap keputusan pembelian konsumen pada kosmetik Wardah di counter wardah di Borobudur kediri.

\section{Analisis keterkaitan variable celebrity endorser, citra merek dan harga terhadap keputusan pembelian}

Berdasarkan penelitian yang dilakukan oleh (Agung 2020) di dapatkan hasil nilai Fhitung sebesar 124,388 dengan nilai signifikansi o,ooo. Sedangkan untuk Ftabel diperoleh nilai 2,70. Maka Fhitung $>$ Ftabel(124,388> 3,09), sehingga secara bersama-sama citra merek, celebity endorser, dan harga berpengaruh secara simultan terhadap keputusan pembelian. Pengaruh yang diberikan variable citramerek, celebrity endorser, dan harga terhadap keputusan pembelian sebesar
78,5\% sedangkan $21,5 \%$ di pengaruhi oleh variable lain yang tidak diteliti oleh peneliti.

Berdasarkan nilai R Sebesar 0.892 artinya ada hubungan yang kuat antara variable celebrity endorser (X1), citra merek (X2), dan harga terhadap variabel keputusan pembelian (Y) Sebesar 89,2\% karena R mendekati 1 sedangkan angka R2 dapat diketahui keputusan pembelian dapat dilihat dari variable celebrity endorser (x1), citra merek (x2) dan harga (x3) terhadap variable keputusan pembelian (y). jumlah y sebesar 0,795 atau $79,5 \%$ sedangkan nilai adjusted R squere sebesar 0,789 atau 78,9\% yang artinya pengaruh determinan variable indevenden $(\mathrm{x})$ terhadap variable devenden (y) sebesar $21,1 \%$.

\section{KESIMPULAN DAN SARAN}

Berdasarkan hasil analisa yang telah dilakukan, maka dapat diambil kesimpulan sebagai berikut:

1. Celebrity endorser berpengaruh signifikan terhadap keputusan pembelian kosmetik wardah pada mahasiswi asrama universitas dharmas indonesia.

2. Citra merek berpengaruh signifikan dan positif terhadap keputusan pembelian kosmetik wardah pada mahasiswi asrama universitas dharmas indonesia.

3. Harga berpengaruh signifikan terhadap keputusan pembelian kosmetik wardah pada mahasiswi asrama universitas dharmas indonesia. .

4. Celebrity Endorser (X1), Citra Merek (X2), dan Harga (X3) berpengaruh signifikan secara silmultan terhadap keputusan pembelian kosmetik wardah pada mahasiswi asrama universitas dharmas indonesia.

\section{SARAN}

1. Bagi mahasiswi, 
Lebih selektif untuk membeli sebuah produk karena banyak produk kosmetik illegal dipasaran yang mengandung zatzat yuang berbahaya seperti mercury dan zat berbahaya lainnya yang tentunya akan menimbulkan efek yang tidak baik bagi kesehatan, selain itu juga lebih selektif dalam membeli produk karena banyak produk palsu yang beredar dipasaran.

2. Bagi peneliti,

Masih banyak kekurangan peneliti dalam menggali data dikarenakan banyak factor salah satunya sulitnya dalam memperoleh data secara langsung, karena teknik pengambilan data dengan menggunakan teknik kuisioner maka banyak sumber data yang dijawab dengan tidak serius, oleh karena itu peneliti menyarankan kepada peneliti selanjutnya untuk melakukan wawancara secara terbuka kepada responden, dan menambah variabel yang tidak diteliti karena masih banyak variabel yang mempengaruhi keputusanpembelian.

\section{DAFTAR PUSTAKA}

Adnan. 2018. "Pengaruh Perilaku Konsumen Terhadap Keputusan Pembelian Susu Morinaga Di Kota Lhokseumawe." Jurnal Visioner \& Strategis 7 (2).

AGUNG, DWI. 2020. "Pengaruh Citra Merek, Selebrity Endorser, Dan Harga Terhadap Keputusan Pembelian Kosmetik Merek Wardah (Studi Kasus Konsumen Wardah Kab. Ponorogo)."

Aktif, farina, Nabila. 2015. "Pengaruh Kualitas Produk, Harga Dan Citra Merek Terhadap Keputusan Pembelian.” Jurnal Fakultas Ekonomi Dan Bisnis Universitas Brawijaya.

Antika, Windi. 2019. "Pengaruh Islamic Celebrity Endorser Dan Islamic Brand Image Terhadap Keputusan Pembelian Kosmetik Wardah ( Studi Pada
Mahasiswi Fakultas Ekonomi Dan Bisnis Islam Iain Purwokerto Tahun 2019 ).”

Aprilia, agung, putu. 2019. "Peran Brand Image Memediasi Pengaruh Celebrity Endorser Terhadap Purchase Intention.” E-Jurnal Manajemen Universitas Udayana 8 (8): 5164. https://doi.org/10.24843/ejmunud.20 19.v08.io8.p17.

Aqmarina, Shabrina. 2016. "Pengaruh Celebrity Endorser Terhadap Citra Merek Serta Dampaknya Pada Keputusan Pembelian (Survei Pada Mahasiswi Fakultas Ilmu Administrasi Universitas Brawijaya Angkatan 2013 Dan 2014 Konsumen Produk Kosmetik Wardah)." Jurnal Administrasi Bisnis S1 Universitas Brawijaya 39 (2): 1-10. Ayuniah, putri. 2014. "Analisis Pengaruh Citra Merek, Kualitas Produk, Iklan Dan Harga Terhadap Keputusan Pembelian Kosmetik Wardah (Studi Kasus Pada Mahasiswi Jurusan Manajemen Fakultas Ekonimi Universitas Gunadarma)" 22 (3): 20819.

Budiyanto, Albert. 2018. "ESENSI: Jurnal Manajemen Bisnis, Vol. 21 No. 3 / 2018" 21 (3): 202-22.

bulgis, tata afifah nur. 2018. "Pengaruh Citra Merek, Kualitas Pelayanan, Kualitas Produk, Dan Harga Terhadap Loyalitas Pelanggan."

Devi. 2015. "Pengaruh Celebrity Endorser Dan Word of Mouth Terhadap Minat Untuk Berpindah Merek ( Brand Switching ) Dengan Perceived Value Sebagai Mediasi." Jurnal Manajemen Pemasaran, 1-10.

Febriani, reni. 2020. "Analisis Pengaruh Celebrity Endorser/Brand Ambasador, Harga Dan Desain Produk Yang Dimediasi Oleh Citra Merek Terhadap Keputusan Pembelian Di Online Shop Shopee." Progress: Jurnal Pendidikan, Akuntansi Dan Keuangan 3 (1): 91- 
109.

https://doi.org/10.47080/progress.v3i 1.782 .

Gloria, Friani. 2018. "Pengaruh Kualitas Produk Dan Harga Terhadap Keputusan Pembelian Mobil Daihatsu Grand Max Pick Up." Jurnal Administrasi Bisnis 6 (2): 86-96.

Hamdani, ikhwan. 2018. "Pengaruh Brand Image Dan Celebrity Endorser Terhadap Keputusan Pembelian Produk Kosmetik Wardah (Studi Pada Perempuan Muslim Di Kota Bogor)," 233-61.

iriani francy, silvia nurfitriana. 2018. "Citra Merek, Kualitas Produk, Harga Dan Pengaruhnya Pada Minat Beli Ulang Produk Kecantikan Wardah." Sebatik 22 (2): 56-63. https://doi.org/10.46984/sebatik.v22i 2.308 .

Irmayanti, rika suhardi dadang. 2019. "Pengaruh Celebrity Endorser, Citra Merek, Dan Kepercayaan Merek Terhadap Minat Beli Konsumen.” Jurnal Inspirasi Bisnis Dan Manajemen 3 (1): 53 . https://doi.org/10.33603/jibm.v3i1.20 86.

maharani, retno, Oktavia. 2020. "Pengaruh Citra Merek Dan Kualitas Produk Pada Kepuasan Konsumen Dimoderasi Oleh Loyalitas (Study Kasus Pada Lipstcik Wardah)." Journal of Chemical Information and Modeling 21 (1): 1-9. https://doi.org/10.1016/j.tmaid.2020. 101607\%oAhttps://doi.org/10.1016/j.i jsu.2020.02.034\%oAhttps://onlinelibr ary.wiley.com/doi/abs/10.1111/cjag.12 228\%oAhttps://doi.org/10.1016/j.ssci. 2020.104773\%oAhttps://doi.org/10.1 016/j.jinf.2020.04.011\%oAhttps://doi. o.

Murdayani, M., Nurbaiti, B., \& Soehardi, S. (2021). The Effect of the Marketing Mix of MSME Products on Sales Volume During the Covid-19 Pandemic The
Effect of the Marketing Mix of MSME Products on Sales Volume During the Covid-19 Pandemic. Journal of Strategic and Global Studies, 4(2), 2740.

https://doi.org/https://doi.org/https:/ /doi.org/10.7454/jsgs.v4i2.1043

Muslimah. 2019. "Pengaruh Citra Merek, Persepsi Harga,Kualitas Produk Dan Celebrity Endorser Terhadap Keputusan Pembelian Produk Wardah Di Puspa Indah Cosmetic Magelang."

Nuraini, Alfiyah. 2015. Pengaruh Celebrity Endorser Dan Kualitas Produk Terhadap Keputusan Pembelian Melalui Citra Merek Pada Kosmetik Wardah Di Kota Semarang. Nhk 技研. Vol. 151.

Pangastuti, jasinta. 2019. "Pengaruh Kualitas Produk Dan Harga Terhadap Keputusan Pembelian Produk Kosmetik Wardah Pada Counter Wardah Di Borobudur Kediri." JIMEK: Jurnal Ilmiah Mahasiswa Ekonomi 2 (1): 69. https://doi.org/10.30737/jimek.v2i1.4 24.

Purnomo, D. 2018. "Pengaruh Credibility Dan Attractiveness Endorser Terhadap Proses Pemilihan Politeknik Lp3I Jakarta Sebagai Tempat Kuliah." Jurnal Lentera Bisnis 7 (2): 40. https://doi.org/10.34127/jrlab.v7i2.23 2.

RICHIRNY. 2017. "Pengaruh Citra Merek dan Harga Terhadap Keputusan Pembelian Pada Produk Pantene ( Studi Iklan Shampo Pantene Pro-v Versi Raline Shah Pada Mahasiswa FISIP USU Medan ).”

Rimiyati, hasnah catur widodo. 2014. "Pengaruh Citra Merek, Kualitas Produk, Kepuasan Konsumen Terhadap Loyalitas Konsumen Merek Samsung Galaxy Series (Studi Pada Mahasiswa 
Muhammadiyah YOGYAKARTA)." Jurnal Manajemen Bisnis 5 (2): 22334.

Soehardi, S., Gobel, D., Soejatmiko, B., \& Syofiansur, M. (2020). Pengaruh Bunaken Brand, Promosi dan Kualitas Pelayanan Terhadap Kepuasan Turis Domestik dan Asing di Provinsi Sulawesi Utara. Jurnal Ilmiah Manajemen Ubhara, 2(1), 9. https://doi.org/10.31599/jmu.v2i1.732 Stefani, Selfi. 2013. "Analisis Pengaruh Iklan Televisi, Celebrity Endorser, Kualitas Produk Dan Citra Merek Terhadap Keputusan Pembelian Pada Produk Kosmetik Berlabel Halal 'Wardah,"' 1-179.

Sugiyono. 2019. Metode Penelitian Kuantitatif, Kualitatif, Dan $R \& D$. Bandung: Penerbit Alfabeta.

Susanto, isnaini nur. 2017. "Pengaruh Kualitas Produk Dan Harga Terhadap Keputusan Pembelian Produk Kosmetik Wardah.” Prosiding Konferensi Nasional 4 (1): 1-9. 